\title{
Toplumsal Cinsiyet ve Teknoloji
}

\author{
Dr. Illkay Savcı \\ A.ü. Siyasal Bilgiler Fakültesi
}

\section{Özet}

1980lerden beri, toplumsal yaşamun tün alanlanında -özellikle çalışma yaşamındadeneyimlenen toplumsal cinsiyet ve teknoloji arasındaki ilişki üzerine bir tartı̧ma sürmektedir. Toplumbilinciler, genellikle teknolojinin toplum üzerindeki etkileri konusunda çalışma eğilimi göstermişler, fakat daima sorulmamıs bir soru kalnışur. Teknolojiyi şekillendiren nedir? Bu soruya cevap vermek için, bazı toplumbilimciler -özellikle feninist yazarlar- "Toplumsal yaplandırmacılık" yaklaşımından türeniş olın "Teknolojinin Toplumsal Şckillennesi" ve bunun bir versiyonu şeklindeki "Teknolojinin Toplumsal Yapılandırılnası" gibi yeni yaklaşımlar üzerine odaklanmışlardır. Bu bokıs açıları, teknolojinin toplumsal olarak yapılandırıldığın ileri sürmektedir. Bu bağlamda, insanlann cinsiyet (büyük ölৎ̧cktc toplum ve kültürün bir ürünü olarak) ve teknoloj̈ arasındaki ilişki ilgili toplunadaki sııf, siyaset, atacrkillik ve kapitalizmin etkileri göz önüne alınmaksızın çözümlenemez. Sonuৎ̧ olarak teknoloji, her zaman ayn sonuçlan üretmez. Bu, teknolojinin şekillenmesi ve uygulanmasımın verolan toplumsal cinsiyet sistemine dayalı olduğunu açık bir şckilde gösterir.

\section{Gender and Technology}

\section{Abstract}

Since 1980 's, there hos been a debate on relationship of gender and technology which is experienced in all areas-especially at work- of social life. Social scientists have generally tended to concentrate on the effects of technology on society. But there has always been a question unasked: What has shaped the technology? To answer this question, some social scientists-particularly feminist writers-focus on new approaches such as the social shaping of technology and its version SCOT (Social construction of technology) which bx)th derive from social constructivism. These perspectives claim that technologics were/are constructed socially. In this context, the relationship of gender (as a product of culture and socicty-large scale) and technology can't be analysed without accounting the effects of class, politics, patriarchy and capitalism in relatod socicty. As a result, technology doesn't always produce the same outcomes. This makes it clear that the shaping and application of technology are dependent on the existing gender system. 


\section{Toplumsal Cinsiyet ${ }^{1}$ ve Teknoloji}

\section{Giriş}

Kadınların ücretli işgücü olarak emck piyasasına girmeleriyle, çalışma yaşamının ve genel olarak toplumsal yaşamın niteliğinde çarpicı değişmeler meydana gelmiştir. Doğal olarak, bu değişimlerin yarattığı çeşitli toplumsal sorunlar, toplumun hemen her kesimi tarafından dogrudan veya dolaylı yaşanarak, çözümlemeye yönelik bir dizi tartışmanın başlamasına sebep olmuştur. İsgücünün bu yeniden yapılanđşı, çalışma ile ilgili tutumlar dahil, çalışma yaşamının çeşitli alanlarında kadın ve erkek farklılıkları ile bu farklılı̆ın kaynaklan ve sonuçları üzerinde odaklanan çok sayıda araştırmanun ortaya çıkmasını sağlamıştır.

Bu noktada çalışmaya başlarken temel ilgimiz, toplumsal yaşam alanının bir parçasını oluşturan ve kaçınılmaz olarak bu daha büyük toplumsal yapının temel özelliklcrinin yansıtıldığı çalı̧̧ma yaşamının içinde "toplumsal cinsiyet rolleri ile teknoloji" arasındaki ilişkinin niteliğini, değişik kuramsal bakış açlarından hareketle açıklamaya çalışmaktır.

"Toplumsal cinsiyet" ve "teknoloji" kavramları arasındaki ilişkinin doğasını açılamaya yönclen çalışmalar, genel olarak teknolojik gerekircilik ve kaynağın 1960'lardan itibaren "toplumsal cinsiyet" tartı̧̧maları ile başlayan feminist akımlardan almı̧ ve özellikle 1990'lardan bu yana etkileri artan "Toplumsal Yapılandırmacilı" (Social Constructivizm) bağlamında, "Teknolojinin Toplumsal Şckillenmesi" (The Social Shaping of Technology) ve bu bakış açısına bağlı olarak "Teknolojinin Toplumsal Yaplandırılması" (SCOT=Social Construction of Technology) yaklaşımları ile yeni bir boyut kazanmıştır (Sundin, 1995; Grint ve Woolgar, 1997; Gill ve Grint 1995; Wajcman 1991a; Webster 1996; MacKenzic ve Wajcman 1993).

Konuyla ilgili literatüre bakıldiğında, genellikle toplumbilimcilerin teknolojinin ya da teknolojilerin insanlar, daha geniş olarak da toplum

1 Toplumsal cinsiyet terimi, ingilizce "gender" kelimesinin karşılı̆ı olarak, bu kavramın biyolojik cinsiyetten (sex) farklı anlamum vurgulanık üzcre kullanılmıştır. 
üzerindeki etkilerini çözümlemeye yönelmiş oldukları görülmektedir. Ancak bazı kuramsal bakıs açlarına göre, toplumu biçimlendiren, teknoloji/teknolojilere şckil veren, onları yapılandıran "şey"in ne olduğu konusu nedense hep ihmal edilmiştir (MacKenzie ve Wajeman, 1993: 2; Sundin, 1995: 347; Wajcman 1991: 29).

Teknolojinin şekillenmesi, üretimi ve kullanılmasında, toplumsal cinsiyetle ilgili ne çeşit varsaymmlar geçerlidir? Teknolojilerin doğal olarak "eril" (masculine) özelliği olup olmadığı, tıp, endüstri ve enformasyon teknolojilerinde tank olduğumuz değişmelerin kadın ve erkek işgörenler için ne anlam taşıdığı, yani kadın işgörenler için yeni fırsatlar sunup sunmadığı, çalışma yaşamında mevcut teknoloji ve işgören ilişkilerinin oluşmasında temel etkenin bizzat teknolojinin doğası olup olmadığı gibi sorular bu tartışma ve araştırmaların temelini oluşturmaktadır.

Toplumsal cinsiyet ve teknoloji arasındaki ilişkinin doğasını keşfetmek için izlenmesi gereken yol, çeşitli kuramsal ve politik tartı̧maların gözden geçirilmesidir. Konu ile ilgili taramalar incelendiğinde, "teknoloji" ve "toplum", aralarındaki ilişkiler açısından cle alınmakta, teknolojilerin üretiminde ve kullanımında toplumsal şckillendirmenin önemine değinilmektedir. Bu bağlamda, teknolojinin toplumsal şekillenişi ve yapılandırılması yaklaşımları, temelde kesinlikle toplumsal olarak yapılandırılmıs olduğu iddia edilen bilimin teknolojiye şckil verdiği, daha sonra önccki teknolojinin bir sonrakini şekillendirdiği ve uzun dönemde aslında toplumun teknolojiye şekil verdiğini tartışmaya açmakta, iddia etmektedir (MacKenzie ve Wajeman, 1993: 4; Crint ve Woolgar, 1997: 19-20).

\section{Teknoloji ve Toplum}

Toplumsal cinsiyet ve teknoloji arasındaki ilişkiyi tartışmaya başlamadan önce, teknolojiyi tanmlamak ve toplumsal cinsiyeti oluşturan, besleyen ve kültürel-toplumsal miras olarak aktaran toplumla teknolojinin ilişkisine açıklama getiren yaklaşımların söylemlerini gözden geçirmek gerekir.

Teknoloji genel olarak yaşanlarımızı örgütlemek amacyla seçtiğimiz bir araç olarak tanımlanabilir. Teknoloji tanumı zaman ve mekana göre değişme gösterirken, örneğin eski Yunan'da "uygulamalı sanat" iken, 20.yy'da araç-gereçler, çalışma süreci hatta tüm çalışna yaşamının örgütlenmesini içeren geniş bir anlama ulaşmıştır. Daha ayruntılı biçimue tanımlanırsa, MacKenzie ve Wajcman, (1993: 3)'a göre teknoloji, a) fizikscl objeler, b) insan eylemleri ile c) bunları birleştiren, bağlayan bilgi ve objelerden oluşmaktadır. Bu tanımlarda cansız fiziksel objelerin "alet" (apparatus), nitclik ve sürec uygulamalarının "tcknik" olarak tanımlanması, alet ile tekniği birleştirecek olan toplumsal düzenlemelerin de örgütlenme olarak betimlenmesi gerektiği ifade 
edilmektedir. Bu iki kavramı bağlayan ağ (network) ise örgütlerdir. Kısaca teknolojinin bütün tanımlarında ortak olan konu bu insani ve insani olmayan unsurların ayrılmaya çalışılmasıdır. "Insani olmayan" daha ziyade maddesel ve teknik içeriğe sahiptir, oysa "insani olan" toplumsal etmenlerle ilgilidir (Grint ve Woolgar, 1997: 8). Diğer yandan makro düzeyde toplumsal yapı göz önüne alındığında Jayawera (1987: 200)'ya göre teknolojiler, yalnızca ekonomik, toplumsal ve siyasi koşulların özel bir biçimde bir araya geldiği, ekonomik ve toplumsal gücün (erk) sömürmeyi ve değişmeyi otomatik olarak planladığı ve garantilediği toplumların olduğu yerde üretilebilir. Bu şekilde oluşturulması, teknolojinin toplum üzcrindeki etkilerinin ne olacağınu çok önceden kestirilmesi ya da belirlenmesi anlamına gelir.

Toplum-teknoloji ilişkisini çözümlemek için konuyla ilgili tartışmanın temelinde yer alan "teknik olan/olmayan" şeklindeki ikicilik (dualizm) üzerinde odaklanmak gerekir. Bu ikili ayırım teknik ve toplumsal etmenleri ayırmaya, toplum-teknoloji ile ilgili varolan üç ana tartışmanın niteliğini açılamaya yardım etmektedir. Bunlardan birincisi teknolojiyi tarafsız (nötr) olarak ele almakta, onu ne şckilde kullandığımızı ön plana çıkarmaktadır. Öyle ki vurgu, teknolojiyi iyi ya da kötü amaçla kullanma tarzlanna yani tüketilme biçimine vurulmaktadır. Bu yaklaşıma göre, teknolojiler etkilerini belirlemezler. Nasıl yorumlanacakları, yorumu yapan aktörlerin teknolojinin belirleyici etkileri olup olmadığına ilişkin inançlarına bağlıdır (Grint ve Woolgar, 1997: 67; Grint, 1993: 280). Çıkarları doğrultusunda yorumlama yapacakları düşünülen aktörlerin ilişki kurma ve yorumlama yollarının gerçekte toplum ve kültür tarafından etkilendiği hesaba katıldığında, bu yaklaşımın toplumsal yapılandırma kuramı ile örtüşen noktalara sahip olduğu görülcbilir.

Ikinci yaklaşım, toplum-teknoloji ilişkisi konusunda çok uzun zaman egemenliğini sürdürmüs olan tcknolojik gerekirciliktir. Bu kurama göre teknoloji, toplumsal ve ekonomik ilişkileri ve örgütlenmeleri zorlayan, yapılandıran, etkileyen kısaca belirleyen bağımsız ve toplum dışından gelen bir değişkendir. Kendiliğinden ve kaçınılmaz olarak gelişir. Şimdiye kadar yalnuz en uygun yeniliklerin hayatta kaldığı ve sadece bu tür yeniliklere uyum sağlayanların başarılı olduğu söylemiyle Darwinci görüşü desteklemektedir. Tıpkı daha önce yaşanan mekanizasyonun mekanik kültürü yaratması ve çalışma yaşamını rutinleştirmesi deneyiminde olduğu gibi, teknolojinin toplumun içerik ve şeklini belirlediği ifade edilmektedir (Grint ve Woolgar, 1997: 10-11). Bazan teknolojik değişim daha gelişmiş, daha üstün bir toplumun teknolojisi ile temas eden geri kalmıs bir ülkede olduğu gibi toplum dışından gelebilmektedir. Bilimin uygulayıcıları olan teknologlar, yeni bilimsel keşiflerin pratik sonuçlarını hesaplayan, üzerinde çalışmalar yapan kişiler olarak algılanırlar. Bilim adamları keşfeder ve teknologlar bu keşiflerin mantığını, onları yeni teknik ve araçlara dönüştürmek için takip ederler. Daha sonra bu 
araç ve tekniklerin topluma tanıtılmasıyla, ekseri tahmin edilemeyen etkileri ortaya çkar. Teknolojinin nasıl bağımsız değişken haline geldiğinin en yaygın açıklamasıdır. Bu özelliği ile teknolojik gerckircilik yalnız geleceğe yönelik değil, aynı zamanda geçmişi açklayan tarihsel bir kuram olarak ta hizmet görür (MacKenzie ve Wajcman, 1993: 4-5).

Teknolojik gerekirciliğin karşıt biçimi olarak tanımlanan üçüncü yaklaşım ise, teknolojinin gelişmesinde belirleyici etmenin toplumun kendisi olduğunu ve teknolojik değişmelerin toplumsal olarak ya da çalışma ilişkileriyle oluşturulduğunu varsayar. Burada vurgu, teknolojinin sosyal şckillenmesi, biçimlenmesi üzerinedir. Bir bakuma toplumsal gerekircilik görece toplumu bağımsız nitelendirmektedir. Böylece bu yaklaşımlar, iki kutupta yer alan gerekirciliğin iki farkl biçimi şeklinde teknolojik ve toplumsal gerekircilik olarak karşı karşlya gelmektedir (Grint, 1993:282; Grint ve Woolgar, 1997: 67).

Teknoloji ile ilgili bu yaklaşımlar özcü (essentialist) ya da özcülüğe karşıt (anti-essentialist) söyleme sahip olarak ikili şekilde de sinıflandırılabilir. Bunlardan birincisi gelencksel yaklaşım başlığı altında, teknolojinin teknik kapasitesinin niteliği üzerinde durur. Bu yaklaşımda, araç-gerę̧ ya da sistemlerde olduğu gibi teknik kapasitenin teknolojiye özgü, doğal bir özellik olduğu ileri sürülür. Çünkü teknik kapasite (yetenck) ler teknolojinin içsel özelliklerinden türemekteđir. Daha da ötesi bu içsel özelliklerin, önceki teknolojik gelişmelere bakılarak doğrudan tahminde bulunulmasından veya bilimsel yöntemin uygulamalarından sonuçlandığı varsayılır. Bu yaklaşım tcknolojik kapasitenin etkilerine ağırlık verdiği ve "toplumsal boyut" tartışmasını sımırladığı için eleştirilere hedef olmuştur (Grint ve Woolgar, 1997: 97).

Özcülük karşıtı olarak nitelendirilen ikinci yaklaşım grubu, aynı zamanda teknolojik gerekirciliğe karşı çkan Toplumsal-teknik sistemler (socio-technical systems) yaklaşımı, toplumsal şekillenme yaklaşımları ki, bu son grup Scot "Teknolojinin toplumsal yapılandırılması"n (Bijker ve diğcrleri, 1987), aktör-ağ (Actor-nctwork) kuramun ya da diğer adıyla çeviri toplumbilimini (sociology of translation) içerir. Bu cok sayıdaki yaklaşım genel olarak, "teknolojik araç-gerecin kapasitesinin, önceki teknolojik durum ve düzey, olaylar ve buluşların doğal sonucu olmadığı" ortak görüşünü paylaşır. Fakat teknolojinin doğa, biçim ve kapasitesinin daha önceki gelişmesi (biçimlendirilmesi ve üretimi dahil) sırasında içerdiği toplumsal koşulların sonucu olduğu ileri sürülür. Bu önceki koşulların oluşturulduğu ve/veya nihai üründe somutlaştığı söylenir. Örneğin feminist araştırmaciların bir kısmı, teknolojinin etkilerinin toplumun atacrkil özelliği ve toplumsal cinsiyet eşitsizliklerinden kaynaklandığın varsayar (Grint ve Woolgar, 1997: 96-97).

Toplumsal- teknik sistemler kuram, üretimin teknik sistemleri ile 
çalışmanın toplumsal sistemi arasındaki bağlar üzerine odaklanur. Model, örgütlerin teknik ve toplumsal sistemlerini bir arada bulunan ve etkileşen iki alt sistem olarak formüllendirir. Ancak kuramsal yaklaşım, çalışma yaşamında ortaya çıkan sorunlannun çözümlenmesinde kullanılırken, teknolojinin toplumsal sistemi tayin etmediği fakat insanlar üzerinde teknolojinin "etkisi" olarak tanumlanabilecek belirli tahminlere ve yorumlara yol açthğ 1 sonucuna ulaşılmıştır (1997: 14-15).

Toplumsal şekillendirme kuram 1980'lerde tartışma alanuna giren ve 1990'lardan bu yana önemi gittikçe artan, toplumsal cinsiyet-teknoloji ilişkisi ile ilgili tartı̧mada daha ziyade feminist toplumbilimciler ve yazarlar tarafından benimsenmiş yaklaşımları kapsar. Bu yaklaşımlar toplumsal yapılandırma kuramından türeyen ve teknolojinin yapılandırılmasında toplumsal etmenlerin etkilerini sorgulayıc yaklaşımlar olarak tanımlanabilir. Toplumsal şckillendirme kuramı, teknolojik sistemlerin gelişmesi ve kullanılmasının ardında yatan toplumsal ilişkileri ve çıkarları araştırır. Teknolojik gerekirciliğe karşı ç karak, yeniliklerin sorunlara çözüm getiren basit bir akılcı-tcknik süreç olmadığın, aynı zamanda çıkarların bağlaşımı, uzmanlığın konuşlandırılması ve geleneksel şekillendirme konularında eril eğilimli aktörlerin varlığını tartışır. Toplumsal şekillendirme yaklaşımı, varolan teknolojilerin yeni tcknolojiler için önemli ön koşul olduğunu ifade eder. Teknolojinin toplumsal ilişkileri, teknolojik gelişmenin özel yolların ya besler ya da dizginler; öyle ki, bir teknolojinin evrimi politik ckonomik, toplumsal ve teknik bir kümenin işievi olarak ortaya çikar (Wajcman, 1991b: 25; Webster 1996: 25-26).

Teknolojinin Toplumsal Yapilandırılması (SCOT) kuramı BIJKER ve diğerleri (1987) tarafından geliştirilmiş̧ir. Bu yaklaşım, özel biçimde teknolojik araç-gerecin, toplumsal aktörlcr arasındaki tartısmaların bir sonucu olan toplumsal yapımlar (constructs) olduğunu ifade etmektedir. Teknoloji yalnuzca "toplumsal aktör"ün yorumlarıyla anlam kazanur. Bazı tcknolojiler yok olurken diğerlerinin yaşamasını sağlayan bir dizi olası teknolojik değişmelerin var olduğu şeklindeki "doğrusal (linear) model"i teknolojik gelişmenin çözümlemesinde kullanır. İlgili toplumsal gruplar araç-gereci anlamlandırırlar. Çünkü onlar gelişmenin örüntüsünü açıklamaya yardım eden çıkarlarıyla bireyler, kurumlar ve örgütlerdir. Çatışmalar farkh toplumsal gruplar arasında ve aynı zamanda farklı teknik seçimler, tercihler ve çeşitli çözümler arasında (ya teknik olan ya da toplumsal ve ahlaki olanlar mümkündür. Araç-gereçlerin biçimlenmesindeki esncklik ve bunlara toplumsal gruplar tarafından iliştirilen anlamlardaki değişmeler (çeşitlenmeler) "yorumlayıcı esneklik" terimi ile ifade edilir. Bununla beraber, teknolojik ürünler olarak araç-gereçler en sonunda dengeye ulaşır; bu kullanım dışı kalmalarına yol açar, yeni bir teknoloji, varolan bu özel teknolojik biçime meydan okuyuncaya kadar bir zaman için sabit kalır ve sonra değişir (Pınch ve Bijker, 1987: 40-45). 
Bir toplumun temel özellikleri hangi teknolojilerin seçileceğine karar vermede büyük öneme sahiptir. Teknolojik gerekirciliğe zarar veren gerçek, "farkl ${ }_{1}$ durumlarda ayn teknolojinin çok farklı etkileri olabileceği"dir. Teknolojiler bilinçli ya da bilinçsiz belirli toplumsal seçeneklere açı, diğerlerine kapalı olmak için gerçekleştirilirler. Teknolojinin toplumsal şckillenmesi üzerindeki çalışma, teknolojik araç gerecin çoğunun oluşumuna biçim veren askeri, endüstriycl, ulusal ve sınıfsal çıkarların biçimini ön plana çıkarmıştır (Gill ve Grint, 1995: 10). Örneğin "mikroçip"in istihdam üzerindeki etkisini belirlemek için, teknolojinin kendisinden ziyade, bilgisayarları üreten endüstrinin doğasın bilmek, yeni işlerin yaratilması ve eskilerin yok olması ile ilgili dolaylı ekonomik etkileri, devlet politikaları ile sendikal hareketin rolünü bilmek gerekir (MacKenzie ve Wajeman; 1993: 6-7)

$\mathrm{Bu}$ bakış açlarından harcketle, teknolojik gelişmenin izlediği yola bakılarak "icat"ların dahi beyinlerin ani esinleri ile keşfettikleri şeyler olmadıkları, icat edilmelcrinin "kaçınılmaz" olduğu ileri sürülmektedir. Örneğin bot (kaylk) ve buhar makinesi biliniyorsa "istimbot"un icat edilmesi kaçınlmazdır (1993: 10-11). Kısaca önceki teknoloji yeni teknolojinin şekillenmesini sağlayan önemli bir etken olmaktadır.

Teknolojinin yapılandırılmasında diğer etmenlerden biri ckonomidir. Tipik teknolojik kararlar ayn zamanda ekonomik kararlardır. Bir adım ileri atarsak, teknolojinin ckonomik şckillenmesinin aslında toplumsal yapılandırılması olduğu ortaya çıkmaktadır. Örneğin kapitalist bir ülkede ürctim teknolojisi kapitalist ihtiyaçlara göre düzenlenir. Teknik değişmede hayati konu maliyetlerdir. Bir sok yenilik bu nedenle himaye bulup desteklenirken, bazı teknolojilerin oluşum ve gelişmesi yavaşlatılır ya da engellenir (MacKenzic ve Wajcman; 1993: 16-17). Örneğin Edison'un elektrik ampulünu icat etmesinin ardında yatan toplumsal ve ekonomik yapılandırmaya bakıldığında şu süreçle karşılaşılmaktadır: Edison clcktriği ürcterek, tüketicilere iletecek bir sistem üzcrinde çalışyordu. Bunu başarmak için olabildiğince düşük maliyetle çalışması gerekiyordu. Maddi olarak bu icadı himaye edip desteklcyenler, ondan bu yeni teknolojinin, eski teknoloji (gazla aydınlanma sistemi) ile rekabet edecek maliyctini hesaplamasını ve kar oranlarını göstermesini istemişlerdi (1993: 13).

Bütün bu açklamalar sonuçta bizi temel konumuza yani toplumsal cinsiyet ve teknoloji ilişkisine getirmcktedir. Hemen hemen bilinen bütün toplumlarda ortak özellik, biyolojik farklhhkların geniş ̧apta toplumșal cinsiyet rollerine dönüştüğüdür. Yukarıdaki açılamalar eşliğinde toplumsal cinsiyet-teknoloji ilişkisine özellikle feminist yaklaşımların bakışı nedir ve mevcut toplumsal cinsiyet düzeni en çarpıcı örneği olan çalışma ilişkilerine nasıl yansımaktadır? 


\section{Toplumsal Cinsiyet (gender) ve Biyolojik Cinsiyet (seks)}

Bu iki terim genel olarak birbirleri yerine kullanılurken, 1960'lardan bu yana değişen toplumsal, ekonomik ve siyasal oluşumlar sonucu anlamları arasında farklılık yaratılmıştır. Toplumsal cinsiyet, cinsiycte dayalı işbölümü ve biyolojik cinsiyetler arasındaki toplumsal ilişkileri vurgulamak amacıyla, toplumda sadece kadınn değil erkeğin de pozisyonunu işaret eden bir kavramdır. Toplumsal cinsiyct teriminin biyolojik cinsiyetle açklanamayan toplumsal sinif, atacrkillik, siyaset ve ilgili toplumdaki üretim biçimleri ile bağlantılı yeni bir anlamı olduğu üzerinde fikir birliği sağlanmıştur (Illich, 1996: 13-15; Webster, 1996: 21).

Her iki kavramın yaşama geçişi toplumsal roller aracılığıyla gerçekleşmektedir. Toplumbilimde rol terimi, bireyin belirli bir mekana getirdiği gelencksel olarak içselleştirilmiş kültürel ve kuralsal beklentileri içerir (Merton, 1970: 245-246). Bu yönüyle bireylerin eylemleri üzerinde kütürel, psikolojik ve kuralsal etkileri vardır. Toplumbilinciler biyolojik cinsiyet rolleri ile, kadın ve erkek arasındaki fiziksel ve biyolojik farkları işaret eden davranışları kastederken, toplunısal cinsiyet rolleri ile dişil ve eril olarak adlandırlan, belirli bir çevrede kültürel ve toplumsal olarak varolan toplumsal etkileşimlerle ilgili, bireylerin toplumsal davranıs ve ilişkilerinde farklılık yaratan örgütlenmiş davranıs örüntüleri olarak tanımlanmaktadır (Magezis, 1996: 4; SpencE ve diğcrleri, 1985: 150).

Toplumsal ve biyolojik cinsiyetle ilgili tartısmada temel konu, kadin ve erkeğin davranış ve rollerinin biyolojik yapı mı yoksa kültür veya toplum tarafından mu tayin edildiğidir. Ilk kez Iskandinav ülkeleri toplumbilimcileri tarafından kullanilan "toplumsal cinsiyet sistemi" terimi "ayrimcilı" ve "hiyerarşi" olarak nitelendirilen iki temel yasa ile toplumsal cinsiyet düzenini açılamaktadır. Sistemin özclliği zaman ve mekana göre değişmesi, toplumsal olarak yapılandırılmasıdır. Toplumisal cinsiyet düzeni, tüm toplumsal sistemde, örgütsel düzeyde, çalışma ilişkileri, iş ve meslek düzeyinde işler. Kadın ve erkekler arasındaki ilişkileri erkekler lchine ayrımcı zihniyetle, kadının erkeğe göre düşük statüsünü toplumsal yaşamın her alanında vurgulayarak örgütler. Oysa kadınlık ve erkeklik biri olmadan diğeri anlaşılmayacak anlamlara sahip kavramlardir (Sundin, 1995: 341).

Toplumda kadınlar tarafından oynanan rollerin, kadının biyolojik özelliklerinden kaynaklandığını söyleyen doğacı (naturalistic) kuram, bu söylemin kanıtları olarak kadının fiziksel bakımdan erkekten zayıf oluşu ve doğurganlığı gibi özclliklerini ileri sürmektedir. Dolayısıyla fiziki üstünlügü nedeniyle crkeğin kadına, doğa ve topluma egemen oluşunu açıklamaktadır. Bu mantıkla toplumsal ilişki ağları kurulmakta ve toplum örgütlenmektedir (Slattery, 1992: 86). Bu tartısmada doğacı kuramın karşısında, geniş bir yelpaze 
oluşturan feminist yaklaşımlar bulunmaktadır. Feminist düşünürler genel olarak toplumsal cinsiyet rollerinin kaynağını toplumun örgütlenme biçimi olarak görürler. Kadının fiziksel zayıflğı konusunda itiraz etmekte, dayanıklılık testlerinde fiziksel kapasitesi olduğunun kanıtlandığını, ayrıca bu farklılıkların toplumsal koşullar değiştikçe değişcbildiğini ileri sürmektedirler. Örneğin, kişilik testleri kadına özgü zayıflık kabul edilen özelliklere erkeklerde de rastlanabildiğini, erkeklerin de kadinlar kadar duygulu olabildiğini göstermektedir (1992: 87).

\section{Toplumsal Cinsiyet ve Teknoloji}

1990'lı yıllardan itibaren yeni bir araştırma alanı olarak teknolojinin feminist bakıs açısından incelenmesi gündemdedir. "Teknolojiler eril özelliktedir" şeklindeki yaygın kanının incelenmesi bir çok kuramsal çalışmanın merkezini oluşturmaktadır. Bu önermeye kaynaklık eden toplumsal cinsiyetle ilgili çözümlemelerde dişil (doğa) ve cril (bilim) olarak kimliklendirilmiş bir dizi farklı değerler kümesi vardır. Bilini temsil eden erkek nesnel, akıla, güçlü ve kişiscl olmama gibi özellikler ile betimleniyorken, doğa ile özdeşleştirilen kadına, öznellik, duygusallik, scvgi ve kişisel olma gibi özellikler atfedilmektedir (Greenbaum, 1990: 11). Bu ikili ayırım analoji yoluyla toplumsal yaşamın her alanına damgasını vurnuştur. Sosyalleşme sürecinde toplumsal rollerin oluşumu ve aktarımında kadın ve erkeğin yaşam alanlarının ayrılarak sinırlandırılması neredeyse kültürel bir evrensellik arz etmektedir. Turkle (1984: 107), her iki cinsin de kendi alanlarmun cfendisi (master) olduğunu, kadının yumuşak (soft), crkeğin sert (hard) egemenlik alanlarının efendisi olarak belirlendiklerini ifade ctmektedir. Her alanın genel özelliklerinin erdemler olarak tanımlanarak bireylerce kabullenilmesinin hiç te şaşıtıcı olmadığın eklemektedir.

Teknolojiyi "eril kültür" olarak görenlerin kullandı̆̆ı anahtar kavramlardan biri "kimlik"tir. Toplumsal cinsiyet kimliğine giren önemli sembolik boyutlar vardır ve erilliğin kısmen teknik yeterlilik yoluyla yapılandırıldığı tartışılmaktadır. Erkeklerin teknoloji ile özdeşleştikleri ve özdeşim biçiminin, birini diğerine bağladı̆̆ı ifade edilmektedir (Wajcman 1991b: 141). Kadınların bu alanda var olmayışları da gerçekte dişil cinsiyet kimliğinin bir parçası olarak tanmlanır. O halde kimlik, erillik ve teknoloji arasında üretilmiş olan doğal ilişki gibi görünmeyi sağlayan önemli bir mekanizma olarak ortaya çımaktadır. Kadının teknoloji alanına girmeme konusundaki ısrarı ve başarısızlığının nedeni onların dişil kimliğinde saklıdır (1991b: 155). Turkle (1984), bilgisayar teknolojisi ile kız ve erkek çocukların ilişkisinde bu gerçeğin altını çizer. Yine Lockheed (1985: 120)'in yaptığı araştırmada, bilgisayar teknolojisinin sadece erkeklere özgün bir buluş olduğu ve kadınların bu alana girmelerinin engellenmesi, küçük yaşta bilgisayarla tanışanların sadece erkek 
çocuklar olduğu şeklindeki bulgular ile açıklanmaktadır. Erkek çocuklara hitap eden ve erkek egemen tutum ve davranışların pekiştirilmesine kaynaklık eden çok sayıda bilgisayar oyunu incelenmiştir. Araştırmacılara göre bilgisayarda kız çocuklar için sunulan hiçbir oyunun olmaması ilginçtir. Bu şckilde yapılandırılan davranş teknolojiye ilişkin tutumu yansitır.

Dişil ve eril kimliğin oluşturulmasına hizmet eden inanışardan birisi de kadın ve erkeğin teknik ycterlilikleri arasında farklllık bulunduğudur. Kadınların zihinsel yeteneklerinin erkeğe nazaran daha zayıf olduğu üzerine bir çok kültürde, "saç uzun aklı kısa" gibi deyimlere dökülmüs kalıplaşmış tutumlar yaşatılır. Kadınların teknik yetencksizlikleri hakkındaki bu biyolojik cinsiyetçi küçümseme sadece populer bir varsayım değil, aynı zamanda bazı akademisyenler tarafından kabul görmüş bir gerşektir. Bu inancı taşıyanlar için teknoloji güçlü, uzak, anlaşılmaz, bilimsel, pahalı ve hepsinden önemlisi erkeğe aittir. Kadınlar mevcut özcllikleri ile teknik işłerde ne yapabilirler? (Gill ve Grint

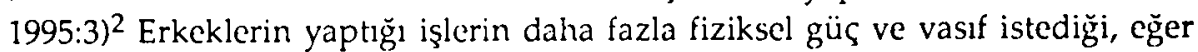
fiziksel gụ̈ gerektirmiyorsa, daha fazla zihinsel yetenck isteyen karmaşıllıkta olduğu inancı, cinsiycte dayalı işbölümününün kaynağı olmuş ve bu işlerin daha değerli ve yüksck ücretli olmaların sağlamıştır. Bunun sonucu olarak işlcrin resmi sınıflandırılnalarında, kadınların yaptığı işlerin yarı vasıflı ya da vasıfsız olarak nitelendiği görülmektedir (Wajeman 1991a: 36). Halbuki, kadınların örgü örme gibi ev işi addedilen uğraşlanı, dikkat çekici biçimde vasıf gerektirir. Deneyim, el mahareti, azımsanmayacak ölçüde sayısal bilgi ve hesaplama gerektirdiği halde, tcknoloji olarak tanımlanmaz. O halde teknolojinin toplumsal bir mülk, hem de erkeğin biçimscl egemenlik araçlarından biri olduğu şcklindeki açılama abartılı olmaz (Cockburn, 1993: 55-56).

Konuyla ilgili kuramsal çalışmalara bakıldığında toplumsal cinsiyet sistemi üzerinde yoğunlaşan feminist kuram dikkat çekmektedir. Teknoloji ve toplumsal cinsiyet ilişkisine yaklaşımda tek bir feminist bakış açısı yoktur. Çeşitli feminist bakış açıları kendi yaklaşımıları doğrultusunda bu ilişkiyi yorumlamaktadırlar. Genel olarak bu bakış açıları, liberal feministler, eko-feministler ve sosyalist feministler şeklinde gruplanabilir: Liberal feminizmde, teknoloji genel olarak eleştirel çözümlemeye konu edilmemekle beraber, geleneksel olarak crkekler tarafından belirlenmiş, tayin edilmiş kabul edilir. Bu formüllendirme, sorunun, kadınarm biyolojik cinsiyetlerinden yansıyan, ne şeşit davranıs ve eylemlerin onlar için uygun olduğuna karar veren, onaylayan toplumsal görüşler tarafından oluşturulmuş sosyal rolleri olduğunu ifade cder ((Webster, 1996: 22). Libcral feministlere göre teknoloji

2 Gill ve Crint in kaynağı için bkı. Faulkner W. ve E. Arnold, (1985: 1), Smothered by Invention (London: Pluto P'ress). 
tarafsız (nötr) dır. Kadın ve erkeği yetenekleri açısından eşit görmekte, ayn temel insanlık ve akılcılığı paylaş̧ıklarımı kabul etmektedirler. Bununla beraber kadınların mevcut potansiyelinin çarpıtıldı̆̆ı, özellikle teknolojiyi kullanma ve uyum sağlama konusunda "yavaş/geri" oldukları şeklindeki yaygın kanının gerçeği yansıtmadığın iddia etmektedirler (Gill ve Crint, 1995: 6). Bu yaklaşımı benimseyen sosyal hareket, çözümü kadınların teknolojik kariyerlere yöneltilmeleri şcklinde belirlemiş ve bu konuda cesaretlendirilmelerini sağlayan kampanyaların oluşturulmasında çok etkili olmuştur.

Eko-feminizm ${ }^{3}$ tcknolojinin tarafsız (nötr) olmadığını, üstelik eril özellik taşıyarak kadın ve doğayı (ki bu iki kavram kadının doğurgan özelliği nedeniyle eşanlamlı kabul cdilmektedir) kontrol altında bulundurduğunu iddia etmektedir (Wcbster, 1996: 23; Mies ve Shiva, 1993: 3; Davion, 1994: 17-20). Eko-feministler, biyolojik ve teknolojik gerckirciliğin kadın ve doğa kavramları ile erkek ve teknoloji kavramlarım özcü (essentialist) ve ikili (dualist) sınıflandırma anlayışııı çözümleme aracı olarak kullanmışlardır (Gill ve Grint, 1995: 4-5). Eko-feministler erkeklerin tcknolojiyi, hem doğaya hem de kadına egemen olma ve onlan kontrol etme için bir araç olarak kullandıklann ileri sürmektedir. Üzcrinde en çok durdukları konulardan biri, erkek-teknoloji ilişkisinin çarpıcı örneği olarak sundukları "askeri teknoloji"dir ve erkek egemenliğinin somut örneği olarak teknolojinin toplumsal yapılandınlması şeklinde tanımlanabilir. Diğer bir konu, doğurganlıkla ilgili teknolojilerin kadın bedeninin ataerkil sömürüsünden başka bir şey olmadığını iddia etmeleridir. Ancak erkeğin doğal yapısını, özünü yansıtması nedeniyle teknolojinin yapılandırılması özcülükten izler taşır (Crint ve Woolgar, 1997: 102-106). Özetle toplum-teknoloji ilişkisinde ortaya çıkan gerçek, toplumun atacrkil doğasından yansıyan teknolojinin ataerkil doğasıdır. Eko-feministlerin ilke edindikleri tek eylem yolu, "dişil değerlerin" kutsanması ve iki ayrı kültürden (kadın ve erkek) oluşan toplumda "kadın kültürünü" geri şckmek yani "ayrilma" (separatism) görüşüdür. Bunun içi kadın dostu "dişil teknolojilerin" üretilmesi ve buna eş giden "kadın-eleştiricilik" (gynocritisizm) ve "kadın-bilim" (gyno-science) gibi kadın entellektüel çalışmalarını yapmak gerckir (Gill ve Grint, 1995: 4-5). Bu yaklaşıma yöneltilen eleştiri, toplumsal cinsiyct-tcknoloji tartışmasında crkeğin biyolojik cinsiyetinden kaynaklanan toplumsal cinsiyet üstünlüğünü eleştirirken, önerileri ile bir çৎşit biyolojik gerekirciliğe saplanmaktan

$31070^{\prime}$ lerrin sonu, 1980' herin başındaaa feminizm, barıs ve ekoloji hareketleri gibi çeşitli sosyal hareketlerden doğan, insan dahil doğadaki yaşamı betimleyen yeni bir antropoloji ve kozmolojiye ihtiyaş duyduğunu, bu nedenle de doğada, karşlıklı sevgi ihtimaam ve işbirliğinin sağlanması gerektiğini ileri süren yaklaşımdır (Mies ve Shiva, 1993: 6 ve 13). Varolan beş cko-feminist bakış açısının her biri, doğadaki ekolojik buhranı çözmeye yardımı amaçlamaktadır. Bu nedenle erkeğin kontrolü ve tchditi altında bulunan kadın da özgürlüğe kavuşmalıdır (Davion, 1994: 17). 
kurtulamamıs, bu kez de kadını daha üstün görme gibi bir açıklama getirmiş olmalaridır (Webster, 1996: 23; Gill ve Grint, 1995: 6).

Sosyalist feminist yaklaşım, kapitalizm ve ataerkilliği her biri diğerini kullanan ve diğeri ile tanımlanabilen bir sistemin parçaları olarak kavramlaştırır. Kapitalizm, cinsiyete dayalı işbölümünün tanımlayıcı bir özelliği kabul edilirken, mevcut işbölümünün ve ilgili teknolojinin toplumsal cinsiyet ilişkileri bu nedenle tarihsel olarak bellidir. Teknoloji çağdaş gelişmiş endüstri toplumunda güce sahip olanlar ve olmayanlar (kapital ve emek) arasında ve kadın ile erkek arasında mücadelelerin sonucu olarak ortaya çkar. Bu yaklaşım, gelişmiş endüstriyel toplumlarda erkeklerin teknolojiye egemen oluşları ve kadınların teknolojik "know-how" ve "yetenek"ten dışlanmalarını tarihsel açıklamayla çözümlemcye çalışır (Webster, 1996: 23-24). Toplumsal cinsiyet-teknoloji ilişkisini sözünılerken, atacrkillik ile egemenlik ve ezilmişlik arasındaki ilişkiyi ortaya çıkarmak ana hareket noktasını oluşturur. Ataerkillik erkek gücünün varlığı ve değerinin onaylandığl, kutsandığı bir yapılandırmadır. Kapitalizm ve atacrkillik birbirlerini besleyen yapilardir. Kapitalizm atacrkilliği kendini gerçekleştirmede kullanırken, ayn zamanda kapitalin bir işlevi olarak ortaya çıkar (Gill ve Grint, 1995: 15).

Eril kültür olarak tcknolojiye bakışta, kadınların teknoloji ile sıkıntılı ilişkisinin, teknik eğitim ve istihdam alanlarına girmeyişlerinden, hatta talep olması halinde bile bu alana girmede isteksizlik göstermelerinden kaynaklandığı iddiasına, eko ve liberal feministlerden eleştiri gelmiştir. Kadının teknoloji alanında yokluğunun, kadın ve erkeklerin dünya ile ilişki kurma yolları arasındaki bazı temel farklıliklardan değil, teknolojinin tarihsel ve kültürel yapılandırılmasından kaynaklandığını ve kadınların kendilerini yeteneksiz ve başarısız algılayışlarında, toplumsal cinsiyete dayalı toplumsal şckillenişin etkili olduğunu ileri sürmüşlerdir. Ortaya çıkan düzenin kaçnılmaz biçimde kadının yabancılaşmasına yol açtığı iddia cdilmiştir (Wajcman 1991b: 19). Nitekim Grint (1993: 280), nesnel olarak yabancılaştırıcı is koşullarının, kadınların yaptığı hemen hemen bütün işlerde bizzat mevcut olduğunu ifade etmektedir.

Feminist bakış açılarının çoğu, geçmişte kadınların teknolojik icatlar yaptıkları ancak bunların göz ardı edildiğini, ancak yine de kadınların teknolojiden korkup çekinmedikleri dönemlerin de yaşanmış olduğunu işaret etmektedirler. Kadınların ürettikleri teknolojilerin tarih kitaplarında bulunmama nedeni, bu teknolojilerin kapitalist karhlık engelini geçememis olmalarıdır. Bu durum toplumsal cinsiyet ile teknoloji arasındaki ilişkinin ideolojik boyutunu işaret etmektedir (Gill ve Grint, 1995: 4; llich, 1996: 120-123; Cockburn 1993.55; Wajcman 1991)

Teknolojilerin toplumsal şckillenişi ve toplumsal yapılandırılması ile ilgili araştırma, aletlerden, makinclere, robotlara, mikroişlemcilere, bilgisayar 
donanum ve yazlımlarına kadar belli bir sayıda teknolojik sistemin gelişimi ve kullanımında iliş̧̧̆i olan toplumsal çıkarlan incelemiştir. Bu teknolojilerin evriminde, açık biçimde toplumsal cinsiyet ilişkileri karı̧̧mı̧ olduğu halde, bunlar ekseri görmezden gelinmiştir. Toplumsal şekillenme incelemeleri, kadınların daha yakından ilişkili olduğu teknolojilerin oluşum ve gelişmesi sırasında, içerdiği toplumsal ilişkilerin farkında olamamıştır. Bununla beraber topumsal şekillendirme bakış açısı, feninist veya toplumsal cinsiyete duyarlı teknoloji çözümlenmesine şok önemli bir potansiyel sunmaktadır (Webster, 1996: 26-27).

Özetle yeni teknoloji, tipik olarak varolan eski teknolojinin birleşimlerinden ve yönlendirilmesinden ortaya çımaktadır. Bununla beraber bu teknolojiyi şekillendiren tek gü̧ değildir. Endüstriyel yenilik belirli toplumsal grupların çıkarlarını, diğerlerinin çıkarlarının aleyhine yerine getiren, tarihsel olarak ta varolan belirli cylemlerin bir ürünüdür. Toplumların ekonomik, politik, sınıfsal vb. gibi örgütlenme biçimleri teknolojinin oluşumunu şckillendirir. Örneğin sosyalist bir toplum, kapitalist toplumdan daha farklı olarak, teknolojinin farklı nitelikte bir biçimini geliştirebilir. Biri işgörenin kontrolü üzerinde önemle dururken, diğeri için böyle bir yapılanma ihtiyacı olmayabilir (MacKenzic ve Wajcman 1993:17). Doğal olarak bu durumda, her iki teknolojinin toplumsal ctkileri de farklllı gösterecektir.

\section{Çalışma Yaşamında Toplumsal Cinsiyet ve Teknoloji}

Çalışma yaşamının örgütlenmesi mevcut toplumsal sistemin yapılanma özelliklerini aynı şekilde yansıtması ile karakterize olur. Kısaca makro yapının kurumlarından biri olarak çalışma örgütlerinde mevcut örgütsel ilişkiler ayn zamanda toplumsal ilişkiler sisteminin bir parçasıdırlar. Toplumda varolan toplumsal cinsiyet ilişkilerinin niteliği gereği, toplumsal yaşamın da ikili özellik göstermesi en çarpıcı örneklerinden birini çalışma yaşamında göstermektedir. Toplumsal yaşamın bütün alanlarındaki ctkileşimlerde olduğu gibi, çalışma yaşamında da kadın ve erkeklerin toplumsal cinsiyet ilişkilerini ve eşitsizliklerini yaşadıkları, hatta ürettikleri bir gerçektir.

Işycrlerinde yaşanan toplumsal cinsiyct teknoloji ilişkilerinin nasıl yapılandığı, bunun kadın ve erkek işgörenlerin iş tutumlarına etkileri üzerine kuramsal yaklaşımlar üç sosyolojik bakış açısı ile sımıflandırılabilir: Yapısalcı (structuralist) yaklaşım, çalışma yaşamunda örgüt ile kadın ve erkek işgörenler arasında gözlemlenen örgütsel ilişkilerin toplumsal cinsiyete atfedilmesinden ziyade işin yapısal özelliklerinden kaynaklanabileceğini ileri sürmektedirler. Teknolojinin seçimi ve kullanımı işin, örgütsel yapının talepleri ile yakından ilişkilidir. Toplumsallaşma (socialisation) yaklaşımı, örgütlerdeki işgören ilişkilerinin temelinde toplumsal cinsiyetle ilgili toplumsallaşmanın yattı̆̆ın, 
tutum ve davranışların toplumdan aktarılan ve doğru kabul edilen toplumsal cinsiyetle ilgili değerler çerçevesinde oluştuğunu ifade etmektedir. Benimsenmiş olan toplumsal cinsiyet rolleri çalışma yaşamı içinde işgörenlerce çalışma rollerine aktarılmaktadır (Smith ve diğcrleri, 1998: 650-653). Teknoloji-isggören ilişkileri, toplumsal cinsiyet sisteminin ayrımo ve hiyerarşik yasaların yansıtır biçimde, teknik vasuf istemeyen düşük statülü işlerde kadınların istihdam edilmesi şeklinde yapılandırılır. Etnometodolojik yaklaşım ise, toplumsallaşma ile yapılandırılan toplumsal cinsiyet ilişkilerinin, çalışma yaşamında kadınlar için çok kath engeller dizisi, katı bir bariyer görevi görerek gelişimlerini engellediğini ve toplumsal cinsiyete dayalı ayrımcliğa maruz bıraktığın ileri sürmektedir. Bu yaklaşım işyerlerinde, toplumsal cinsiyet sistemine dayalı olarak, kadınların istemedikleri iş ve konumiara adeta hapsedildiklerini iddia etmektedir (Miller ve Loessi, 1992: 9-10).

Toplumsal yaşam alanı, cinslerin farklı biyolojik özelliklerine bağlanması mümkün olmayan toplumsal cinsiyete dayalı işbölümü temelinde, kadın ve erkeklerin farklı işler yaptığı, iki toplumsal yaşam alanına (kamusal ve özel alanlar) bölünmüş̧ür. Bu işbölümünde, crkcklerin eylemleri genellikle kadınların cylemlerinden daha değerli kabul cưlir. Kadınların pek bulunmadığı kamusal alanda (public sphere) erkekler egemendir. Toplumların çoğunda karar verme alanı olarak tanımlanır. Ücretli işgücü olarak bu alana adım atmaya çalışan kadınlar, mevcut toplumsal cinsiyet sisteminin engelleri ile karşılaşmaktadır. Oysa kadınlar, kendileri için tanımlanmı̧ özel alanda (private sphere) yer alırlar. Temel görev annelik ve ev işleri olarak belirlenir. Bu alan klişcleştirilmiş olarak aşağı statüde bulunur. Aslında annelik, belagatla kutsansa bile, pratikte bu hem ekononik zaafi hem de "ekmek kazanan" erkeğe - bağımlılı̆̆ı getirir (MacKenzie ve Wajcman, 1993: 18).

Feminist araştırnaciların önemle üzerinde durdukları emek süreci kavramı, kadın ve erkek arasındaki bu ayrıma bağlı olarak, mesleklerin toplumsal cinsiyet yanlı sınflandirılmasına dikkat çeker. Madencilik, metal işleri, diğer vasıflı imalat işleri, teknik vasıf gerektiren işler vb. erkek işidir. Kadınların özel alandaki eylemleri kamusal alanda yapabilecekleri işlere damgasını vurur. Sckreterlik, hemşirclik, öğretmenlik, bakım, temizlik ve yemek işleri vb. gibi işler dişil özcllik taşır.Bu işlerde kullanılan teknolojiler, genel olarak çok fazla teknik bilgi ve zihinsel yctenek gerektirmez Bu işlere kadının yatkınlığı, duygusallık ve sabırllık gibi onun yapısal özelliklerine atfedilen değerlerle açıklanır. Bu yapılanma, kadını otomatik olarak erkeğin egemenliğindcki tcknoloji alanından uzakta tutar. Cinsiyete dayalı mesleki ayrımcllk yapısal bir süres ise, işlerin toplumsal cinsiyete dayalı sınıflandırılması da bu yapılanmanın daha önceden belirttiğimiz gibi kültürel ve ideolojik yönünü yansitır (Webster, 1996: 18-20). Böylece işlerin toplumsal cinsiyete dayalı olarak kalıplaşması kadının aile içindeki geleneksel rollerinin 
sadece yansıması değil, aynı zamanda ücretli çalışmanın ataerkil ilişkileri tarafından yaratılıp biçimlenmesidir. Bazı toplumbilimciler, yeni teknolojik gelişmelerin, fiziksel zorluğu olduğu için kadınların dışlandığı işleri kaldıracağın, dolayısıyla bu alandaki kadın ve erkek işleri arasındaki sınırların kalkacağın ummuşlardır. Aksine, toplumsal cinsiyet ilişkileri dikkat çekici biçimde sabit kalmıştır (Wajcman, 1991a: 33).

Toplumsal cinsiyet ve teknoloji ilişkisi açısından dikkat çckici bir konu, kadın işgörenlerin istihdam özellikleri açısından ortaya çkmaktadır. Kamusal alana girerek emek piyasasında yer alan kadın işgörenlerin üç özelliği vardır. Birincisi, cinsiyet klişeleştirilmesinden dolayı her iş onlara açık değildir; ikincisi, erkeğe nazaran daha az kazanırlar; üçüncüsü işücünün geçici üyeleri olarak muamele görürler, yedek işücü ordusunu oluştururlar ve bu nedenle örgütlenme ve sendikalı olmaları güçtür (Cowan, 1993: 53). Bu bağlamda, endüstri alanında teknolojinin şekillenmesine etki eden koşullar şu şekilde ortaya çıkar: İşerenler, vasıflı erkek işçilerle kolayca yer değiştirmeyi sağlayacak, düşük ücretli ve sendikalaşma oranı düşük kadın işgörenlerin çalıştırılmasın mümkün kılan teknolojik değişme biçimlerine yönelirler. Çünkü yeni bir makine yüksek maliyet içerir. Bu nedenle düşük maliyetli kadin emeğinin bol olduğu endüstrilerde teknolojik gelişme daha yavaş seyredebilir (MacKenzie ve Wajcman, 1993:18; Wajcman 1991a:40).

Yeni teknoloji eskisinin yerini alırken, vasfa göre tabakalanmış işgücü bünyesinde rahatsızlık yaratabilir.Yukarıda sayılan nedenlerle teknoloji tekelini doğal haklan gören erkek işgörenler, gerektiğinde güçlerini göstermek için örgütlenmektedirler. Çünkü erkeğin istihdam olanağı, işverenlerin pahalı vasıflı erkek işgörenleri baltalama eğilimi ve düşük kadın işgören maliyetleri ile tehdit altındadır. Yeni teknolojiyle birlikte, her ne kadar bazı vasıflı erkek işgörenler işlerini kaybederse ve yerlerine kadın işgörenler yerleştirilirse de, kadın için nadiren değişme gerçckleşir. Kadın emeğinin düşük vasıflı olarak tanımlanışı nedeniyle, erkeklerden boşalan yerlere kadınlar geçtiğinde, artık o iş düşük vasıflı olarak sınıflandırılacaktır ve ücret bu yeni tanuma göre belirlenecektir (Wajcman, 1991a: 31-35). Bu süreç aynı zamanda kadınların eşit işe eşit ücret alamama nedenini açıklamaktadır.

Son olarak söz edilmesi gereken yapılanma, ofis otomasyonu ile ilgilidir ve toplumsal cinsiyet-teknoloji ilişkisini açk bir şckilde yansıtan bir iş organizasyonu sunmuştur. Kadınların çalışma yaşamına girişleri çok eski olmakla beraber, işgücü içindeki oranları Il.Dünya Savaşı sonrasından itibaren, endüstriyel ve ofis tipi işlerde ortaya çıan yeni teknoloji ve düzenlemeler sonucu arḩ̧ göstermiştir. Çalışma yaşamında özellikle 1960'ların sonlarında otomasyonun etkinliğinin artması ile gündeme toplumsal cinsiyet ve bilgisayarlaşma ile ilgili örgütlenme sorunları gelmiş, cinsiyete dayalı işbölümü bağlamında cinsiyete dayalı mesleki ayrımcilik populer bir inceleme ve 
araştırma konusu olarak ortaya çkmıştır. Bu yeni teknoloji ile ilişkili olarak "beyaz yakalı" işlerde kadın işgören oranları hızla artmıs, bilgisayar donanımlı ofisler kadınlara ait iş alanları olarak tanımlanmıştır. Yine de zihinsel yetenek istediğine inanılan, sistem analistliği ve bilgisayar teknolojisi kullanulan hesaplama ve mühendislik işleri, erkeklerde kalmıştır (Cutek ve Bikson 1985: 124-125).

Iş süreci ve çalışma ilişkileri açısından bir çağ açtı̆̆ ileri sürülen otomasyonu, bazı yazarlar kadınların vasıflı işlere geçmesini kolaylaştıracak bir teknoloji olarak görürken, diğer bazı feminist yazarlar bu konuda karamsar kalmışlardır. Emck süreci ile ilgilenen bu yazarlar, ofisleri üretim bantının beyaz yakalı kopyası olarak nitelendirdiler. Cerçekten de ofis tipi işler, her biri uzmanlaşmış işgörenler tarafından yerine getirilen, çok sayıda alt göreve ayrılmıs, hem çeşitlilik özelliğini kaybetmiş, hem de toplam nihai ürünle işgörenin ilişkisini kesen bir çalışma tarzı yaratmıştır. Sonuç, işgörenin iş üzerindeki kontrolünün gittikçe azalması olmuştur (Wajcman, 1991a: 31). Bu tür işin klasik örneği veri girişidir. Tek düze, hızlı, sayısal kontrol getiren ve erkeklerin kadınlar için uygun gördükleri bir iş alanıdır.

Bilgisayar teknolojisi ile çalışmak zorunda kalan kadın işgörenler için, toplumsal cinsiyet sisteminin etkileri olarak yorumlanan sosyal-psikolojik bir sorun, teknostres ve teknofobi olarak tanimlanabilir. Kadinin toplumsal cinsiyete dayalı kalıp düşünceler etkisiyle teknolojiye karşı kendini yeteneksiz, dolayısıyla yetersiz alglladığ ve bu nedenle bilgisayarla başa çıamama korkusu şeklinde yaşadığı bir rahatsızlıktır. (Hudiburg ve d. 1989: 767). Bu durum kadınların teknolojiye ilişkin tutumların yansıtmakla beraber, arkasındaki toplumsal yapılandırmanm niteliğini göstermesi bakımından ilginৎ̧ bir örnektir.

Buraya kadar gerek çalışma yaşamında gerekse toplumsal yaşamda mevcut toplumsal cinsiyet sisteminin ve teknoloji ile ilişkisinin toplumsal olarak şekillendiği üzerinde durulmuştur. Konuyla ilgili olarak son yıllarda SCOT ekolü ile bağlantılı olarak örgütsel seviyede enformasyon sistemleri ile ilgili artan bir yazın vardır. Bunlar içinde çok sayıda çalışma toplumsal cinsiyeti dikkate almıştır. Bu çalışmalarda toplumsal cinsiyetin örgütscl kültürün önemli bir parçasını oluşturduğu kabul edilmektedir (Sundin, 1995; Wajcman, 1991; MacKenzie ve Wajeman;). Özellikle feminist hareketin daha çok ilgi gösterdiği bu araştırma alanundaki bulgular, zaten bilinen yaplanmanun boyutların göstermesi açısından ilginçtir. Bu araştırmalardan bazı örnekler vererek, kuramsal açıklamalarm saha çalışması ile desteklendiğini göstermek uygun olacaktur.

Sundin (1995)'in İsveç'te SCOT kuramsal yaklaşımından hareketle yaptı̆̆ iki vaka çözümlemesinde aynı teknolojiyi (CAD) seçen iki mimari ofiste, teknolojinin farklı sonuçlar yarattığına dikkat çekmektedir. Birinci ofiste, CAD 
teknolojisi tartışmalar sonucu bir çizim aracı olarak tanumlanmamış, mühendis ve mimarlar tarafından kullanılarak, kadın olan teknik ressamlar daha aşağı iş pozisyonlarına geçirilmiştir. ikinci ofiste ise, kazananlar kadın teknik ressamlar olmuş, erkekler alan kadınlara bırakmışlar ve CAD kadın işi olarak etiketlenmiştir. Araştırma ayns teknolojinin farklı sonuçların işaretle, toplumsal yapılandırmaya örnck oluşturmaktadır. O'Donnell'in Avusturalya'da giyim endüstrisinde yaptı̆̆ı araştırmaya göre bu yüzyıl boyunca makine, hem kadın hem erkek işgörenler tarafından kullanılmıştır. Ancak, aynı işi yapmalanına rağmen kadınların (makinistler) işi vasıfsız, erkeklerin (makasçlar) işi ise vasıfı olarak sınıflandırılmıştır. Bu ayrım ücretlere de aynen yansıtılmaktadır. Teknolojinin toplumsal cinsiyetle ilişkili olarak farklı sonuçlarına işaret eden bir araştırmadir (Wajcman 1991a: 37) ${ }^{4}$.

Diğer bir olayda, Londra Flect caddesinde konuşlanan gazetecilik endüstrisinin 1986'da gazeteci ve reklam personelinin metni dogrudan bilgisayara girmelerini sağlayacak teknolojiyi üretime geçirmeye teşebbüsü üzcrine, bu teknoloji işgörenlerin vasıflarına saldırı gerekçesiyle protestolarıyla karşılaşmıştı. Grev ve lokavtlar peşpeşe geldi, sonuç olarak teknolojinin uygulanışını geciktirdi. Yeni teknolojinin arkasında yatan vasıfsızlaştırma süreci, işi kadınların yapabileccği hale getiriyor, iş üzerindeki kontrolü ortadan kaldırıyordu ve işverenler için ucuz emekle yer değiştirme olanağı sağlıyordu (Wajcman 1991a: 35).

Noble yapmıs olduğu araştırmada, otomasyonun yarattı̆̆ biçimde bir gelişme göstermek zorunda olmadığını göstermiş ve aksine otomasyonun kasıtlı biçimde seçilmiş ve uygulanmıs olduğunu ortaya çıkarmıştır (1991a: 40). ${ }^{5}$ Örneğin, durağan bir yapllanma gösteren örgütler, bilgisayar teknolojisini kontrolü merkezileştirmek için, böyle bir şevreyc sahip olmayan işletmeler, merkezileşmemiş bir yapının kurulması amacıyla kullanmaktadırlar (Grint ve Woolgar, 1997: 25).

Yine istatistiklere göre, Ingiltere'de mühendislik endüstrisinde 1980 yılında kadınların \%93'ü sekreterlik, ofis memuru, operatör, temizlik ve yemek işlerinde çalışıorken, mühendis olarak çalışan personelin sadece \%2'sinin kadın olması ilginçtir (Cockburn, 1993: 55).

Daha eski dönemlerden örneklere bakılırsa, endüstri devrimi surasında tarım iş̧̧iliğinin ücretli hale gelmesiyle, orak kullanarak çalışan kadınlar, yerlerini erkek işçilere bıraktılar. Işten alınma nedeni iki tutamaklı olarak geliştirilen tırpanın kadınların kullanamayacağı kadar ağır olmasıydı. Yine

4 Wajcman'ın kaynağı için bke. ODonncll, C. (1984), The Basis of The Bargain: Gender, Schooling and Jobs, (Sydncy: Allen \& Unwin).

5 Wajcman'ın kaynağı için bkı. Noble, D. (1984), Forces of Production: A Sociaal History of Industrial automaation, (New York: Alfred $A$. Knopf). 
1930 'da Ingiltere'de posta idaresi, kentlerde paketlerle dolu ağır posta çantasını taşıyamayacaklan gerekçesiyle kadın işgören kullanmıyordu. Fakat ayn kurum, kursal alanda ayn iş için kadın postacılar çalıştırıyordu (Grint ve Woolgar, 1997:104). Bir başka örnekte Valerie Frissen, telefonun kamusal alanda iş görüşmeleri için geliştirilmiş bir teknoloji olarak kullanma sunulduğunu, ancak toplumsal etkileşim için ortam hazırlayarak en fazla kadınlar tarafından kullanıldığının ortaya çıkması ile birlikte, o günlerde görüşmek için telefon bağlayan operatörlerin kadınlar arasından seçilmeye başlandığın ve bu işin bir kadın mesleği haline getirildiğini ifade etmektedir (Gill ve Grint, 1995:23)6.

Bu ve benzeri araştırma sonuçları, yapılandırılmıs toplumsal cinsiyet ve teknoloji ilişkilerinin toplumsal yaşamın her alanında, özellikle de çalışma yaşamında etkilcyici örnekler oluşturduğunu açk biçimde göstermektedir. Gerck toplumsal şckillenme kuramı, gerekse SCOT, çalışma yaşam alanının örgütlenmesini ve toplumsal ilişkilerini çözümlemek için farklı bir bakıs açsı ve özgün araştırma konuları sunmaktadır.

\section{Sonu̧}

Bu çalışmada, son yıllarda toplumbilim, endüstri ilişkileri, siyaset alanında oldukça ilgi çekmiş olan toplumsal cinsiyet-tcknoloji tartı̧ması ve konuyla ilgili çȩ̧itli yaklaşımların görüşleri aktarılmaya çalışılmıştır. Öncelikle, toplumsal cinsiyet sistemini üreten toplumun teknoloji ile ilişkisi, teknolojik gerekirciliğin bakış açısından hareketle açıklanmıs, daha sonra bu kuramın karşısında yer alan ve bir dizi yaklaşımı içeren toplumsal şekillendirme kuramı görüşlerine yer verilmiştir. Teknolojinin temel olarak bağımsız bir değişken rolü oynayarak, toplumsal olan ne varsa biçim ve niteliğini etkilediğini, hatta oluşturduğunu ileri süren teknolojik gerekirciliğe, aralarında feminist yazarların da yer aldığı toplumbilimciler temelde birbiri ile örtüssen iki yaklaşımla cevap vermektedirler. Birincisi teknolojilerin kendi etkilerini belirleyemeyecekleri, yorumlarının, yorumu yapan aktörlerin "teknolojilerin belirleyici etkileri olup olmadığına" ilişkin inançlarına bağlı olduğunu ileri süren yaklaşımdır, ikinci yaklaşım ise, teknolojinin toplumsal ctkilere sahip olmadan önce, içinden çıktı̆̆ toplumun örgütlenme biçiminden (ekonomi, politika, kültür, sınıfsal yapı, ataerkilik, toplumsal cinsiyet sistemi vb.) türediğini ifade etmektedir. Bu bağlamda, teknoloji toplum ilişkisini açılayan yaklaşımlar, toplumsal cinsiyet-teknoloji ilişkisinin niteliğinin açıklanmasında kuramsal bir temel oluşturmaktadır.

6 Gill ve Grint'in kaynağı için bkz. Frisssen, V. (1992), "Trappedo in Electronic Cages? Gender and New Information Technologies in the Public aand P'rivate Domain: An Overview of Research", Media, Culture And Society, 14, 31-49. 
Toplumsal cinsiyet-teknoloji arasındaki ilişkinin sorgulanmasına en büyük ilgi feminist araştırmacılardan gelmektedir. Feminist yaklaşımların toplumsal cinsiyeti kavramlaştırma biçimlerine bağh olarak teknolojiyle ilişkisine getirdikleri açıklamalar genellikle bu ana kuramsal yaklaşımları kullanmaktadır. Toplumsal ilişkiler sisteminin bir parçası olarak, toplumsal cinsiyet sistemi işyeri kültürünü oluşturarak, özellikle ayrımalık ve hiyerarşi taşıyan yapılandırması ile hem toplumsal cinsiyct-teknoloji ilişkisini, hem de çalışmanın toplumsal ilişkilerini düzenlemektedir. Yukarıda sözü edilen toplumsal şekillendirme ve teknolojinin toplumsal yapılandırılması (SCOT) yaklaşımları doğrultusunda toplumsal cinsiyet-teknoloji ilişkilerinin şekillenmesinde, aktörlerin mevcut teknolojiyi yorumlayışlarında, toplumsal-kültürel, ekonomik, sinifsal, politik ve atacrkil etmenlerin etkileri araştırma sonuçları ile birlikte verilmeye çalışılmıştır.

\section{Kaynakça}

BIJKER, W.E., T.P'.Hughes ve T.J.Pinch (1987), The Social Construction of Technological Systems: New Directions in the Sociology and History of Technology, (Cambridge, MA: MIT Press)

COCKBURN, Cynthia (1993), "Caught in the Wheels: The High Cost of Being a Female Cog in The Male Machinery of Engineering", The Social Shaping of Technology, (Buckingham: Open University Press) (Der: D. Mackenzie ve J. Wajcman)

COWAN, Ruth S. (1993), "Ciender and Technological Change", The Social Shaping of Technology, (Buckingham: Open Ĺniversity l'ress) (Der: D. MacKenzic ve J. Wajeman)

DAVION, Victoria (1994), "Is Ecofeminism Feminist?", Ecological Teminism, (London:Routledge) (Der: Karen J.Warren)

GILL, Rosalind ve Keith Crint (1995), "The Cender-Technology Relation: Contemporary Theory and Rescarch," The Cender-Technology Relation: Contemporary Theory and Research, (London: Taylor and Francis Lud. 1-29)

GREENBAUM, Joan (1995), "The Head and The Heart: Using Ciender Analysis To Study The Social Construction of Computer Systems", Computers And Sociely, 20/2, 9-17

GRENT, Keith (1993), Sociology of Work: An Introduction, (Cambridge: Polity Press)

GRINT, Keith ve Steve Woolgar (1997), The Machine At Work: Technology, Work And Organization (Cambridge:l'olity l'ress)

GUTI:K, Barbara ve T.K. BIKSON' (1985), "Differential Experiences of Men and Women in Compulerized Offices", Sex Roles, 13/3, 124-126

HUDIBURG, Richard, S.R.Brown ve T.M.jones (1989), "Measuring Technostress: Computer Related Stress", Psychological Reports, 64, 765-772

ILl.ICH, Ivan (1996), Genuler, (Ankara: Ayraç Yayınevi) (Çev: A. J'ethi)

JAYAWERA, N.D. (1987), "Communication Sutellites: A Third World P'erspective", Information Technology: Social Issues, (Seven Oaks: Hodder and Stoughton /Open University Press) (Der: R.Finnegan, G.Salamon ve K. Thompson)

LOCKFIFFD, Marlaine E (1985), "Women, Girls and Computers: A First laokk At The Evidence", Sex Roles, $13 / 3,115-122$ 
MacKENZIE, Donald ve Judy Wajcman (1993), "Intruductory Essay: The Social Shaping of Technology," The Social Shaping of Technology, (Buckingham: Open University) (Der: D.MacKenzie ve J.Wajcman)

MAGEZIS, Joy (1996), Women's Studies, (I ondon: Teach Yourself Books)

MERTON, Robert K. (1970), "The Role-Set" Modern Sociology: Introducing Readings, (Penguin Books) (Der: P.Worsley).

MIES, Maria ve Vandana Shiva (1993), "Introduction", Ecofeminism, (Halifax:Fernwood Publications) (Der: M.Mies ve V.Shiva)

MII.LER ve LOESSI, K (1992), "Toward Gender Integration in The Workplaces: Issues At Multiple Levels", Sociological Perspectives, 35/1, 1-15.

SLATTERY, Martin (1992), Key ldeas in Sociology, (London: Thomas Nelson and Sons Publishers)

PDNCH, T.J. ve E.Bijker (1987), "The Social Construction of Facts and Artefacts. Or How The Sociology of Science and The Sociology of Technology Might Benefit Each Other", The Social Construction of Technological Systems: New Directions in the Sociology and History of Technology. (Cambridge MA: MIT Press) (Der: W.L:Bijker ve diğgerleri)

S.MTTH, Patricia L.J.Smiths, F.Hoy (1998), "Iimployce Work Attitudes: The Subtle Influence of Gender," Human Relations ,51 /5, 649-666.

SI'ENCE, Janct, K.Deaux ve R.L.Helmreich (1985), "Sex Roles in Contemporary American Society", Handbook of Social Psychology, (New York: Random House) (Der: G.lindsey ve E.Aronson)

SUNDIN, Elisabeth (1995), "The Social Construction of Cender and Technology," The European Journal of Women's Studies, 2, 335-35.3.

TURKLE, Sherry (1984), The SecSelf: Computers and Iluman Spirits (London: Granada Publishing Lid.)

WNJCMAN, Judy (1991a), "Patriarchy, Technology and Conceptions of Skill," Work And Occupations, 18/1, $29-45$.

WAJCMAN, Judy (1991b), Feminism Confronts Technology (Cambridge: Polity)

WEBSTER, Julict (1996), Shaping Women's Work: Gender, Employment and Information Technology (London: Longman Socioligy Serics). 